\title{
Pengaruh Pendekatan Pendidikan Matematika Realistik Indonesia (PMRI) Terhadap Keterampilan Berpikir Kritis Siswa SD
}

\author{
Arrum Meirisa $^{1 *}$, Ronal Rifandi $^{2}$, Masniladevi $^{3}$ \\ ${ }^{1,2}$ STKIP Adzkia, Kota Padang, Sumatera Barat 25175, Indonesia \\ ${ }^{3}$ Universitas Negeri Padang, Kota Padang, Sumatera Barat 25175, Indonesia
}

Pengiriman: 4 Agustus 2018; Diterima: 29 September 2018; Publikasi: 30 September 2018

DOI: https://doi.org/10.31629/jg.v3i2.508

\begin{abstract}
Abstrak
Penelitian ini bertujuan untuk mengetahui apakah terdapat pengaruh pendekatan PMRI terhadap kemampuan berpikir kritis siswa dan bagaimana proses belajar menggunakan pendekatan PMRI terhadap keterampilan berpikir kritis siswa di kelas V SD Negeri 44 Kalumbuk Kota Padang. Jenis penelitian ini adalah Eksperimen. Desain yang digunakan adalah Quasi Experimental dan rancangannya Posttest Only Control Design. Subjek penelitian ini adalah siswa kelas V SD Negeri 44 Kalumbuk Kota Padang, yang terdiri dari dua kelas yaitu kelas VA sebagai kelas kontrol dan kelas VB sebagai kelas eksperimen. Data yang diperoleh dengan tes akhir dianalisis dengan menggunakan uji- t. Hasil penelitian dengan menggunakan uji normalitas dan homogenitas terhadap kedua data berdistribusi normal dan homogen. Selanjutnya dilakukan uji hipotesis dengan uji-t menunjukkan $t_{\text {hitung }}=3,04$ dan $t_{\text {tabel }}=1,673$ dengan $d f=55$ dan taraf signifikan $5 \%$. Berdasarkan pengujian $t_{\text {hitung }}>t_{\text {tabel }}$ maka $\mathrm{H}_{0}$ ditolak dan $\mathrm{H}_{1}$ diterima dengan kesimpulan penggunaan PMRI memberikan pengaruh terhadap keterampilan berpikir kritis siswa di kelas V SD Negeri 44 Kalumbuk Kota Padang tahun ajaran 2017/2018.
\end{abstract}

Kata kunci: PMRI; berpikir kritis

\begin{abstract}
This study aimed to determine whether there is an influence of the PMRI approach on students' critical thinking skills and how the learning process using PMRI approach in grade V of SDN 44 Kalumbuk Padang is. This study was a quasi experimental research with Post-test Only Control Design. The subject in this study were students of VA and VB of SDN 44 Kalumbuk Padang in academic year of 2017/2018. The data collected through post test was analyzed with $t$ test. The $t$-test result shows that $t_{\text {count }}=3,04$ and $t_{\text {table }}=1,673$ with $\mathrm{df}=55$ and alpha $5 \%$. Based on the result, it is concluded that the PMRI approach gives a positive influence to the students' critical thinking skills in grade V of SDN 44 Kalumbuk padang in academic year 2017/2018.
\end{abstract}

Keywords: PMRI; critical thinking

\section{Pendahuluan}

Matematika merupakan ilmu yang berperan sebagai dasar dalam perkembangan *Penulis Korespondensi Email Address: arrummeirisaudefi@gmail.com Handphone : : +62 8153586931 teknologi modern, dan memiliki kaitan erat dengan berbagai disiplin ilmu. Matematika juga merupakan mata pelajaran yang perlu diberikan 


\section{JURNAL GANTANG. September 2018; III(2): 127 - 134 \\ p-ISSN. 2503-0671 \\ e-ISSN. 2548-5547}

kepada semua siswa untuk membekali dan menunjang siswa dengan berbagai ilmu pengetahuan dan teknologi (Depdiknas, 2006). Pembelajaran matematika di sekolah dasar menunjukkan bahwa matematika tidak hanya sebatas penguasaan fakta dan prosedur matematika serta pemahaman konsep tetapi juga beberapa keterampilan matematika (Puspita, 2015). Keterampilan ini dapat terbagi dua yaitu keterampilan berpikir tingkat tinggi dan keterampilan berpikir tingkat rendah. Salah satu keterampilan berpikir tingkat tinggi adalah keterampilan berpikir kritis yang merupakan keterampilan yang sangat berguna dalam kehidupan sehari-hari (Rahmi \& Alberida, 2017). Sehubungan dengan itu, siswa di sekolah dasar diharapkan mampu memiliki keterampilan berpikir kritis dalam menyelesaikan persoalan yang terkait dengan matematika. Maka guru berperan untuk memfasilitasi siswa agar mampu memiliki keterampilan tersebut.

Glaser (Fisher, 2008) mendefinisikan berpikir kritis sebagai: (1) suatu sikap berpikir secara mendalam tentang masalah-masalah dan hal-hal yang berada dalam jangkauan pengalaman seseorang, (2) pengetahuanpengetahuan tentang metode pemeriksaan dan penalaran yang logis, dan (3) semacam suatu keterampilan untuk menerapkan metode-metode tersebut. Dalam keterampilan berpikir kritis diharapkan ada usaha yang sungguh-sungguh untuk mengkonfirmasi asumsi dengan mencari bukti yang kuat beserta kesimpulan berikutnya yang timbul. Sedangkan, menurut ahli lainnya berpikir kritis adalah kemampuan dan kecendrungan seseorang untuk membuat dan melakukan penilaian terhadap kesimpulan yang didasarkan pada bukti (Eggen \& Kauchak, 2012).

Salah satu pendekatan pembelajaran matematika yang dapat membantu siswa dalam mengembangkan keterampilan berpikir kritisnya adalah pendekatan Pendidikan Matematika Realistik Indonesia (PMRI). Ahli menyebutkan bahwa pendekatan PMRI adalah pendekatan yang menempatkan realita dan pengalaman siswa sebagai titik awal pembelajaran
(Kusumaningtyas, Wardono, \& Sugiarto, 2013).

PMRI menggunakan realitas dan keadaan yang dapat dibayangkan oleh siswa untuk digunakan dalam proses pembelajaran guna mencapai tujuan pembelajaran matematika yang dirumuskan. Dunia nyata digunakan sebagai titik awal di dalam PMRI untuk pengembangan ide dan konsep dalam pembelajaran matematika (Rifandi, 2017). Beberapa penelitian lainnya juga menyatakan tentang pentingnya konteks dunia nyata digunakan dalam pembelajaran matematika (Febrian \& Perdana, 2017; Rifandi, Budiarto, Lukito, Abels, \& Dolk, 2014).

Jika penanaman konsep matematika sesuai dengan pendekatan yang digunakan dan melatih kemampuan siswa untuk berpikir kritis, maka dalam pembelajaran siswa bisa mengemukakan ide serta kemampuannya. Sehingga tujuan pembelajaran bisa tercapai dengan baik dan hasil belajar siswa maupun keterampilannya dalam berpikir kritis bisa lebih meningkat.

Pendekatan PMRI tentunya mempunyai tahapan dalam pelaksanaanya, Pendapat ahli menyatakan bahwa ada empat tahap dalam pendekatan PMRI, yaitu: 1) tahap pendahuluan, 2) tahap pengembangan model simbolik, 3) tahap penjelasan alasan, dan 4) tahap penutup (Hadi, 2005). Menurut Filasaime (Karim \& Normaya, 2015) indikator berpikir kritis yaitu: (1) menginterprestasi, (2) menganalisis, (3) mengevaluasi, dan (4) inferensi. Indikator Filasaime ini akan digunakan dalam pendekatan PMRI karena memiliki rubrik penilaian tes kemampuan berpikir kritis.

Pengumpulan data awal dalam penelitian ini yaitu melalui observasi, wawancara dengan guru kelas V pada SD Negeri 44 Kalumbuk Kota Padang, dan memberikan tes tentang keterampilan berpikir kritis kepada siswa. Berdasarkan hasil observasi dan wawancara yang dilakukan maka dapat disimpulkan, beberapa hal diantaranya: (1) pada proses pembelajaran guru lebih aktif daripada siswa, (2) pemberian masalah yang berhubungan dengan 
dunia nyata siswa belum terlihat, (3) pada proses pembelajaran metode yang digunakan guru masih menggunakan hafalan rumus-rumus dan belum terlihat mengaitkan dengan hal konkret yang ada disekitar siswa, (4) siswa belum bisa mengembangkan model sendiri dalam menyelesaikan masalah dari bentuk konkret ke abstrak, (5) siswa banyak yang pasif dan kurang paham dalam pembelajaran matematika.

Setelah melakukan observasi dan wawancara kepada guru kelas V SD Negeri 44 Kalumbuk Kota Padang, untuk memperkuat data tentang keterampilan berpikir kritis siswa, maka dalam penelitian ini peneliti mengadakan tes. Tes yang diberikan adalah berupa soal cerita untuk melihat keterampilan berpikir kritis siswa. Setelah diberikan tes, maka diperoleh rekapitulasi nilai tes keterampilan berpikir kritis dengan simpulan bahwa kemampuan siswa dalam menyelesaikan soal yang berkaitan dengan keterampilan berpikir kritis masih sangat rendah.

Solusi dari gambaran permasalahan tersebut menunjukkan bahwa pembelajaran matematika perlu diperbaiki guna mengembangkan keterampilan berpikir kritis siswa. Keterampilan berpikir kritis merupakan cara berpikir tentang suatu masalah yang dialami oleh seseorang, berdasarkan berbagai metode yang terdapat bukti pendukung dan penarikan kesimpulan dalam menyelesaikannya. Sehingga, dalam pengaplikasiannya perlu suatu pendekatan pembelajaran yang menunjangnya. Hal ini ada kaitannya dengan pendekatan PMRI mengaitkan antara matematika dengan kehidupan sehari-hari dan kegunaan matematika yang umum bagi siswa.

Berdasarkan penjelasan di atas, maka dalam penelitian ini peneliti merumuskan masalah sebagai berikut "Apakah terdapat pengaruh positif penggunaan pendekatan PMRI terhadap keterampilan berpikir kritis siswa kelas V SD Negeri 44 Kalumbuk Kota Padang?". Sejalan dengan rumusan masalah tersebut, maka tujuan dari penelitian ini adalah untuk melihat pengaruh dari penggunaan pendekatan PMRI terhadap keterampilan berpikir kritis di sekolah yang menjadi subjek penelitian ini.

Selanjutnya, peneliti mengajukan hipotesis penelitian sebagai berikut:

1. $\mathrm{H}_{0}=$ Tidak terdapat pengaruh positif penggunaan pendekatan PMRI terhadap keterampilan berpikir kritis siswa di kelas V SD Negeri 44 Kalumbuk Kota Padang.

2. $\mathrm{H}_{1}=$ Terdapat pengaruh positif penggunaan pendekatan PMRI terhadap keterampilan berpikir kritis siswa di kelas V SD Negeri 44 Kalumbuk Kota Padang.

\section{Metode Penelitian}

Penelitian ini termasuk dalam penelitian eksperimen. Penelitian eksperimen merupakan penelitian yang dimaksudkan untuk mengetahui ada tidaknya akibat dari "sesuatu" yang dikenakan pada subjek selidik. Dengan kata lain penelitian eksperimen mencoba meneliti ada tidaknya hubungan sebab akibat (Arikunto, 2010).

Penelitian ini menggunakan Quasi Experimental Design atau disebut eksperimen semu. Quasi Experimental Design adalah suatu desain penelitian yang memiliki kelompok kontrol tetapi tidak dapat berfungsi sepenuhnya untuk mengontrol variabel-variabel dari luar yang mempengaruhi pelaksanaan eksperimen (Sugiyono, 2009). Rancangan penelitian yang digunakan adalah Posttest Only Control Design, dalam desain ini, untuk memperoleh kelompok kelas kontrol dan kelompok kelas eksperimen, anggota kelompok tidak diambil secara acak, namun langsung ditentukan sesuai dengan anggota tetap yang ada dimasing-masing kelas tanpa diacak ulang (Creswell, 2012). Kelompok yang diberikan perlakuan disebut kelompok eksperimen (kelas eksperimen) dan kelompok yang tidak mendapat perlakuan disebut kelompok kontrol (kelas kontrol). Penetapan kelas kontrol dan kelas eksperimen ini diawali dengan melakukan uji normalitas dan uji homogenitas untuk mendapatkan sampel yang representatif dalam penelitian ini. 


\section{JURNAL GANTANG. September 2018; III(2): 127 - 134 \\ p-ISSN. 2503-0671 \\ e-ISSN. 2548-5547}

Tabel 1.

Posttest only control design

\begin{tabular}{|c|c|c|l|}
\hline a. & $\begin{array}{c}\text { Select } \\
\text { Control } \\
\text { Group }\end{array}$ & No Treatment & Posttest \\
\hline b. & $\begin{array}{c}\text { Select } \\
\text { Experimental } \\
\text { Group }\end{array}$ & $\begin{array}{c}\text { Experimental } \\
\text { Treatment }\end{array}$ & Posttest \\
\hline
\end{tabular}

Sumber: (Creswell, 2012)

Berdasarkan tabel 1 maka pada kelas ditentukan menjadi dua, yaitu kelas kontrol dan kelas eksperimen. Pada kelas kontrol tidak diberikan perlakuan, namun pada akhir pembelajaran diberikan posttest. Sedangkan, pada kelas eksperimen diberikan perlakuan dan pada akhir pembelajaran diberikan posttest.

Penelitian ini, terbagi atas 3 tahapan atau langkah agar penelitian berlangsung secara terarah, sistematis, dan sesuai dengan tujuan. Adapun langkah-langkahnya terdiri atas persiapan, pelaksanaan, dan analisis data.

Tahapan persiapan, yang terdiri dari a) melakukan identifikasi masalah dengan melakukan observasi awal dan tes kemampuan berpikir kritis studi pendahuluan mengenai keterampilan berpikir kritis siswa kelas V di SD Negeri 44 Kalumbuk Kota Padang, b) menentukan subjek penelitian sebagai kelas eksperimen dan kelas kontrol, c) menyusun Rencana Pelaksanaan Pembelajaran (RPP) yang berhubungan dengan penelitian yang akan dilaksanakan, d) membuat kisi-kisi uji coba, e) menyusun soal uji coba sesuai dengan kisi-kisi yang telah dibuat, f) melakukan validasi RPP, dan soal uji coba kepada tim ahli, g) melakukan uji coba soal di SD Negeri 33 Kalumbuk Kota Padang, dan h) melakukan uji validitas, reliabilitas, daya pembeda soal, dan tingkat kesukaran untuk mencari soal yang dipakai dan soal yang direvisi ataupun dibuang. Setelah didapatkan simpulan, maka akan dijadikan soal untuk posttest.

Tahap pelaksanaan, terdiri dari a) menyiapkan pendekatan PMRI sesuai dengan materi yang diajarkan, b) melakukan proses pembelajaran pada kelas eksperimen dengan menggunakan pendekatan PMRI, c) proses pembelajaran pada kelas kontrol tetap di ajar oleh guru kelas, atau peneliti tidak memberikan perlakuan, dan d) setelah perlakuan selesai diberikan, selanjutnya melakukan posttest baik di kelas kontrol maupun dikelas eksperimen. Hasil tes digunakan untuk mengetahui keterampilan berpikir kritis siswa setelah treatment dilakukan.

Tahap analisis data, yang terdiri dari a) mengolah data hasil tes siswa, dan dilanjutkan dengan pengujian statistik untuk menguji hipotesis, b) menarik kesimpulan hasil penelitian, dan c) menyusun laporan mengenai penelitian yang sudah dilaksanakan.

Instrumen yang digunakan pada penelitian ini yaitu tes keterampilan berpikir kritis. Data yang diperoleh pada penelitian ini dianalisis dengan menggunakan Microsoft Office Excel 2007 dan program SPSS versi 21.

Teknik analisis data yang digunakan pada penelitian ini adalah uji normalitas, uji homogenitas, dan uji hipotesis. Uji normalitas data digunakan untuk mengetahui data hasil penelitian berdistribusi normal atau tidak. Dalam penelitian ini, teknik pengujian normalitas data dilakukan menggunakan uji Liliefors dengan melihat nilai signifikansi pada kolomogorovSmirnov. Data dikatakan normal apabila nilai signifikansi lebih besar dari 0,05 (Priyatno, 2012).

Uji homogenitas tujuannya adalah untuk mengetahui apakah kelas sampel mempunyai variansi yang homogen atau tidak. Uji homogenitas data dalam penelitian ini dilakukan dengan uji levene menggunakan bantuan program SPSS versi 21. Data dikatakan homogen apabila nilai signifikansi lebih besar dari 0,05 (Priyatno, 2012).

Uji hipotesis bertujuan untuk melihat pengaruh penerapan PMRI terhadap keterampilan berpikir kritis siswa. Peneliti menggunakan uji-t untuk mengetahui hipotesis apabila data berdistribusi normal dan mempunyai variansi homogen. Rumus uji-t adalah sebagai berikut: 
$\mathrm{t}=\frac{\bar{X}_{1}-\bar{X}_{2}}{S \sqrt{\frac{1}{n_{1}}+\frac{1}{n_{2}}}}$ dengan

$$
S=\sqrt{\frac{S_{1}{ }^{2}\left(n_{1}-1\right)+S_{2}{ }^{2}\left(n_{2}-1\right)}{n_{1}+n_{2}-2}}
$$

Keterangan:

$\overline{X_{1}}=$ Nilai rata-rata kelas eksperimen

$\overline{X_{2}}=$ Nilai rata-rata kelas kontrol

$\mathrm{S}=$ Standar deviasi kedua kelas sampel

$S_{1}^{2}=$ Variansi kelas eksperimen

$S_{2}^{2}=$ Variansi kelas kontrol

$\mathrm{n}_{1}=$ Jumlah siswa kelas eksperimen

$\mathrm{n}_{2}=$ Jumlah siswa kelas kontrol

(Supardi, 2013)

Keputusannya:

Kriteria terima $\mathrm{H}_{1}$ jika $\mathrm{t}_{\text {hitung }}>\mathrm{t}_{\text {tabel. }}$

\section{Hasil dan Pembahasan}

Berdasarkan penelitian yang telah dilakukan pada kelas subjek penelitian, maka diperoleh data mengenai keterampilan berpikir kritis siswa kelas V SD Negeri 44 Kalumbuk Kota Padang pada pembelajaran matematika. Data diperoleh melalui tes akhir yang dilakukan pada akhir penelitian. Soal tes akhir berupa essai sebanyak 6 butir soal. Jumlah siswa pada kelas eksperimen yang mengikuti tes akhir sebanyak 29 orang dan jumlah siswa kelas kontrol yang mengikuti tes akhir berjumlah 28 orang.

Data keterampilan berpikir kritis siswa pada pembelajaran matematika dengan materi "Menggunakan pecahan dalam masalah perbandingan dan skala" dapat dilihat nilai tes akhir yang diperoleh siswa. Dari tes akhir diperoleh data sebagaimana pada tabel berikut:

Tabel 2.

Perhitungan data tes akhir belajar matematika pada kelas penelitian

\begin{tabular}{|l|c|c|c|c|c|}
\hline $\begin{array}{l}\text { Kelas } \\
\text { sampel }\end{array}$ & $\mathbf{N}$ & $\overline{\boldsymbol{X}}$ & $\boldsymbol{S d}$ & $\boldsymbol{X}_{\text {maks }}$ & $\boldsymbol{X}_{\text {min }}$ \\
\hline Eksperimen & 29 & 77 & 19.37 & 100 & 29 \\
\hline Kontrol & 28 & 60 & 23.49 & 100 & 20 \\
\hline
\end{tabular}

Pada tabel terlihat bahwa nilai rata-rata berpikir kritis matematika siswa kelas eksperimen $(\bar{X}=77)$ lebih tinggi dari rata-rata siswa kelas kontrol $(\bar{X}=60)$. Perbandingan rata- rata kelas eksperimen dan kelas kontrol dapat dilihat pada grafik berikut ini.

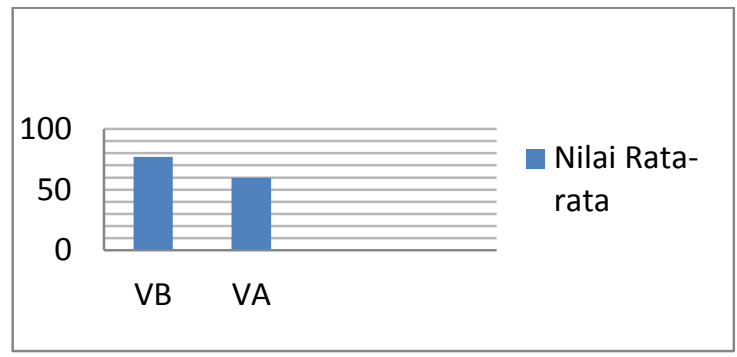

Grafik 1. Rata-rata nilai kelas eksperimen dan kelas kontrol

Selanjutnya untuk menentukan apakah data hasil siswa di atas berdistribusi normal dan homogen, maka peneliti melakukan uji normalitas dan uji homogenitas. Hasil dari uji normalitas tes akhir dapat dilihat dari tabel 3 di bawah ini

Tabel 3.

Hasil uji normalitas tes kemampuan berpikir kritis

\begin{tabular}{|ll|r|r|r|}
\hline \multirow{2}{*}{ kelas } & & \multicolumn{3}{|c|}{ Kolmogorov-Smirnov $^{\mathrm{a}}$} \\
\cline { 3 - 5 } & & Statistic & \multicolumn{1}{c|}{$\mathrm{df}$} & \multicolumn{1}{c|}{ Sig. } \\
\hline \multirow{2}{*}{ nilai } & V A & .080 & 28 & $.200^{*}$ \\
& V B & .133 & 29 & $.200^{*}$ \\
\hline
\end{tabular}

Berdasarkan tabel 3, nilai signifikan yang diperoleh pada keterangan kolom kolmogorov-smirnov $\quad 0,200$ pada kelas eksperimen dan kelas kontrol. Nilai ini lebih besar dari taraf $\alpha 0,05$. Maka dapat dikatakan bahwa data tes berpikir kritis berdistribusi normal. Sedangkan hasil uji homogenitas dapat dilihat pada tabel 4 berikut ini

Tabel 4.

Hasil Uji Homogenitas Tes Kemampuan Berpikir Kritis

\begin{tabular}{|c|c|c|c|}
\hline $\begin{array}{l}\text { Levene } \\
\text { Statistic }\end{array}$ & df1 & df2 & Sig. \\
\hline 1.780 & 1 & 55 & .188 \\
\hline
\end{tabular}

Berdasarkan Table 4 terlihat signifikan dari uji levene adalah 0,188 > 0,05 (taraf tingkat kesalahan/penolakan) maka dapat dikatakan bahwa data tes berpikir kritis berdistribusi 


\section{JURNAL GANTANG. September 2018; III(2): 127 - 134 \\ p-ISSN. 2503-0671 \\ e-ISSN. 2548-5547}

homogen.

Setelah data tes akhir keterampilan berfikir kritis matematika siswa dihitung berdistribusi normal dan homogen, maka pengujian hipotesis akhir dilakuan dengan mengguakan uji t-test. Uji t-test dilakukan dengan cara membandingkan data dua kelompok sampel, atau membandingkan data antara kelompok eksperimen dengan kelompok kontrol, atau membandingkan peningkatan data kelompok eksperimen dengan peningkatan data kelompok kontrol yang telah normal dan homogen (Supardi, 2013).

Kriteria $\mathrm{H}_{1}$ diterima jika $\mathrm{t}_{\text {hitung }}>\mathrm{t}_{\text {tabel. }}$ Jadi untuk mencari $\mathrm{t}_{\text {tabel }}, \mathrm{dk}=\mathrm{n}_{1}+\mathrm{n}_{2}-2$ sama dengan $\mathrm{dk}=28+29-2=55$. Berarti, $\mathrm{t}_{\text {tabel }}$ yang dilihat pada signifikansi 0,05 dengan titik presentase distribusi $\mathrm{t}(\mathrm{dk}=55)$ yaitu $\mathrm{t}_{\text {tabel }}=1,67303$. Setelah itu, bandingkan antara $t_{\text {hitung }}$ dengan $t_{\text {tabel }}$. Diperoleh $t_{\text {hitung }}=3,04>t_{\text {tabel }}=1,67303$. Maka dapat disimpukan bahwa $\mathrm{H}_{1}$ diterima atau terdapat pengaruh positif pendekatan PMRI terhadap keterampilan berpikir kritis siswa.

Secara keseluruhan pelaksanaan pembelajaran di kelas eksperimen dengan menggunakan pendekatan PMRI berjalan lancar. Pendekatan PMRI merupakan pendekatan pembelajaran yang berpusat pada siswa dimana guru dapat memfasilitasi siswa untuk membangun sendiri pengetahuan mereka tentang dunia nyata. Sebelum pembelajaran dimulai, guru berusaha membangkitkan minat dan keingintahuan siswa terhadap materi yang akan dipelajari dengan mengaitkan materi dengan kehidupan sehari-hari tentang menggunakan pecahan dalam masalah perbandingan dan skala. Kemudian siswa membangun pengetahuan mereka dengan anggota kelompok yang kemudian dilanjutkan dengan siswa mendiskusikan pengetahuan yang mereka peroleh dan menyelesaikannya, disini siswa menyelesaikan soal dengan alat peraga yang digunakan untuk menyelesaikan soal secara nyata seperti menggunakan kelereng, peta dan lain-lain. Setelah itu siswa diberi kesempatan untuk mendiskusikan, dan mencari alternatif jawaban yang benar, kemudian siswa diminta mempresentasikan jawaban dari penyelesaian soal yang dilakukannya di depan kelas menggunakan penjelasan sendiri. Kemudian, diakhir kegiatan guru mengarahkan siswa untuk menarik kesimpulan.

Hal ini sejalan dengan yang dikemukakan oleh Hadi (2005) tentang tahaptahapan pembelajaran dengan pendekatan PMRI. Jadi, pendekatan PMRI dapat dikatakan pendekatan dalam pembelajaran yang berpusat pada siswa, sehingga dengan pendekatan PMRI siswa dapat menemukan sendiri konsep yang terkait dalam pembelajaran dan mereka dapat lebih mudah memahami pembelajaran matematika hal ini seperti yang sudah dideskripsikan dalam kegiatan pelaksanaan pembelajaran.

Pada pengerjaan LKS sudah mulai terlihat bahwa siswa sudah bisa mengerjakan LKS sesuai dengan indikator keterampilan berpikir kritis. Hal ini sesuai dengan Filasaime (Karim \& Normaya, 2015) indikator berpikir kritis yaitu: (1) menginterprestasi, menganalisis, (3) mengevaluasi, dan inferensi. Pada lembar jawaban LKS siswa sudah terlihat bahwa, siswa sudah bisa menyelesaikan soal yang berkaitan dengan keterampilan berpikir kritis. Selain itu juga sudah terlihat adanya tahapan pengembangan model simbolik pada pendekatan PMRI yang muncul saat siswa menyelesaikan persoalan yang ada pada LKS. Kemudian siswa sudah dapat mengembangkan jawaban sendiri dalam menyelesaikan masalah dari bentuk konkret ke bentuk abstrak.

Berbeda dengan kelas eksperimen, pelaksanaan pembelajaran di kelas kontrol dengan menggunakan metode ceramah dan tanya jawab, dimana gurulah yang menjadi pusat perhatian siswa dan sebagian besar informasi yang diperoleh bersumber dari guru sehingga siswa kurang aktif pada proses pembelajaran. Kegiatan pembelajaran pada kelas kontrol yaitu guru menyampaikan tentang materi yang diajarkan, memberikan contoh soal kemudian memberikan latihan tentang materi pembelajaran 
yang telah diajarkan oleh guru.

Berdasarkan analisis data yang telah didapatkan, terlihat bahwa ada pengaruh terhadap keterampilan berpikir kritis siswa pada kelas eksperimen yang belajar dengan menggunakan pendekatan PMRI dengan siswa kelas kontrol yang tidak menggunakan pendekatan PMRI pada pembelajaran matematika. Hal ini dapat dilihat dari rata-rata kelas eksperimen 77 dan kelas kontrol 60 . Perbedaan tersebut dapat dilihat melalui uji hipotesis yaitu uji $t$-test. Dimana pada uji $t$-test diperoleh $t_{\text {hitung }}=3,04>t_{\text {tabel }}=1,67303$.

Dengan demikian berarti $H_{o}$ ditolak dan $H_{1}$ diterima yang berarti“"terdapat pengaruh positif pendekatan Pendidikan Matematika Realistik Indonesia (PMRI) terhadap keterampilan berpikir kritis siswa di kelas V SD Negeri 44 Kalumbuk Kota Padang”. Diterimanya $H_{1}$ menunjukkan bahwa pembelajaran dengan menggunakan pendekatan PMRI ini dapat diterapkan di sekolah untuk meningkatkan keterampilan berpikir kritis siswa sekolah dasar.

\section{Kesimpulan}

Berdasarkan hasil penelitian yang peneliti lakukan, dapat diambil simpulan bahwa terdapat pengaruh pendekatan PMRI matematika terhadap keterampilan berpikir kritis siswa. Selanjutnya peneliti ingin memberikan beberapa saran sebagai berikut yaitu kepada guru untuk menerapkan pendekatan PMRI ini secara berkelanjutan atau berkesinambungan supaya keterampilan berpikir kritis siswa dalam pembelajaran matematika terus meningkat. Di samping itu, agar penelitian selanjutnya lebih memperhatikan indikator berpikir kritis dan alokasi waktu yang digunakan.

\section{Ucapan Terimakasih}

Pada penelitian ini, peneliti mengucapkan terimakasih kepada kepala sekolah beserta guru dan staf SD Negeri 44 Kalumbuk Kota Padang yang telah memberi izin untuk penelitian ini.

\section{Referensi}

Arikunto, S. (2010). Edisi revisi: manajemen penelitian. jakarta: pt. rineka cipta.

Creswell, J. W. (2012). Educational research: planning, conducting, and evaluating quantitative and qualitative research (4th ed.). Boston: Pearson.

Depdiknas. (2006). Kurikulum tingkat satuan pendidikan. Jakarta: Depdiknas.

Eggen, P., \& Kauchak, d. (2012). strategi dan model pembelajaran. Jakarta: Indeks.

Febrian, \& Perdana, S. A. (2017). Memfasilitasi penalaran geometri transformasi siswa melalui eksplorasi motif melayu dengan bantuan grid. Jurnal Gantang, ii(2), 157164. https://doi.org/10.31629/jg.v2i2.250

Fisher, A. (2008). Berpikir kritis, sebuah pengantar. Jakarta: Gelora Aksara Pratama.

Hadi, S. (2005). Pendidikan matematika realistik dan implementasinya. Banjarmasin: Tulip.

Karim, \& Normaya. (2015). Kemampuan berpikir kritis siswa dalam pembelajaran dalam pembelajaran matematika dengan menggunakan model jucama di sekolah menengah pertama. Edu-Mat, 3(1).

Kusumaningtyas, W. K., Wardono, \& Sugiarto. (2013). Penerapan PMRI terhadap kemampuan pemecahan masalah matematika berbantuan alat peraga materi pecahan. Unnes Journal of Mathematics Education, 2(1), 76-83. retrieved from http://journal.unnes.ac.id/sju/index.php/ujm e\%0apenerapan

Priyatno, D. (2012). Belajar cepat olah data statistik dengan spss. Yogyakarta: Mediakom.

Puspita, V. (2015). Developing pupils' reasoning skills by using modified investigation approach. in prooceeding (pp. 426-428).

Rahmi, Y. L., \& Alberida, H. (2017). Improving students' higher order thinking skills through portfolio assessment on biology curriculum and textbook analysis course. Bioeducation Journal, 1(1), 22-33.

Rifandi, R. (2017). Supporting students' reasoning about multiplication of fractions 
JURNAL GANTANG. September 2018; III(2): 127 - 134

p-ISSN. 2503-0671

e-ISSN. 2548-5547

by constructing an array model. Journal of Research and Advances in Mathematics Education, 1(2), 99-110.

Rifandi, R., Budiarto, M. T., Lukito, A., Abels, M., \& Dolk, M. (2014). Developing grade 5 students ' understanding of multiplication of two fractions through taking a part of a part of a whole activity. In R. Ilma (Ed.), The Second South East Asia Design/ Development Research (SEA-DR) International Conference (pp. 272-278). Palembang: Unsri.

Sugiyono. (2009). Metode penelitian pendidikan (pendekatan kuantitatif, kualitatif, dan $R \&$ $D)$. Bandung: Alfabeta.

Supardi. (2013). Analisis statistik dalam penelitian konsep statisitik yang lebih komprehensif. Jakarta: Change Publication. 